\title{
Recent Themes of Colombian Scientific Engineering Journals in Scopus
}

\author{
Marco Aguilera-Prado ${ }^{1}$ \\ Vice-presidency for Research \\ Universitaria Agustiniana \\ Bogotá, Colombia
}

\author{
Octavio José Salcedo Parra ${ }^{2}$ \\ Faculty of Engineering \\ Universidad Distrital Francisco José \\ de Caldas, Bogotá, Colombia
}

\author{
Eduardo Avendaño Fernández ${ }^{3}$ \\ Faculty of Engineering \\ Universidad Pedagógica y \\ Tecnológica de Colombia \\ Tunja, Colombia
}

\begin{abstract}
Through a co-occurrence bibliometric and citation analysis of 1.272 texts published in the four Colombian engineering journals available in Scopus between 2014 and 2018, this paper identified that most articles belong to supply chain optimization and logistics and involve work with information that requires minimal laboratory experimentation. Works applying artificial neural networks, clustering, and genetic algorithms are also prominent. Results from researching on biomass analysis on bioenergy and sustainability are more recent and are present to a lesser extent. Most of the reference texts of the articles published come from Spanish-speaking countries and mostly cite DYNA, the European Journal of Operational Research, the Journal of Food Engineering, and Ingeniería e Investigación.
\end{abstract}

Keywords-Co-occurrence words; bibliometric analysis; bibliometrics; Colombian journals

\section{INTRODUCTION}

The dynamics of Colombian journals in the Scielo database show that: i) Colombian journals are the leading destination of texts with Colombia affiliation; between 2002 and 2013, 12,534 articles (81.9\%) were published in these journals; ii) the journals with most articles published were Biomédica (449), Revista de Salud Pública (438) and Agronomía Colombiana (369); iii) most collaboration is between Colombian authors (56\%), whereas the most prominent international collaboration was with Spain (438, 2.9\%), Brazil (422, 2.8\%), and the USA (418, 2.8\%). Furthermore, both the titles of the journals where articles are published, and the articles' themes show that health sciences, engineering, and biology are the most significant fields of the bibliographic production of Colombian scientific research published in the region's journals [1].

Regarding engineering journals in Scopus, the searching results shows four Colombian journals under the Engineering (miscellaneous) category: DYNA (Universidad Nacional de Colombia), Revista Facultad de Ingeniería (Universidad de Antioquia), Ingeniería e Investigación (Universidad Nacional de Colombia), and Ingeniería y Universidad (Pontificia Universidad Javeriana). These journals have been publishing research and review articles in multiple areas of engineering at a national level for over 20 years and have been indexed in Scopus for 10 years.

According to SJR, a detailed look at the quartile classification shows that: i) the four journals were part of quartile three in 2017; ii) DYNA achieved quartile two between 2012 and 2016; iii) in 2017, the classification by SJR showed that Ingeniería and Investigación $(0,189)$ in the first place, followed by Revista Facultad de Ingeniería $(0,172)$, DYNA $(0,167)$, and Ingeniería y Universidad (0.161), and iv) the h-index shows DYNA (11) in the first place, followed by Revista Facultad de Ingeniería (9), Ingeniería e Investigación (7) and Ingeniería y Universidad (4), which are relatively low indexes compared to similar journals in quartile three.

It was also found that: i) generally, the Colombian academic production on engineering comes mainly from Universidad Nacional and Universidad de Antioquia, and focuses on recognized Latin American journals such as DYNA, Revista Facultad de Ingeniería, and Revista Ingeniería e Investigación [2]; ii) it is characterized for the low citation of its articles [2], and iii) about half of the texts on Colombian engineering journals in Scopus are written in Spanish, by authors from non-English speaking countries [3].

The possible reasons for why this citation indicators go along the various characteristics of scientific production may be grouped in three sets [4]: aspects of the journals (impact, language of publication, field, form of publication (conference, journal, proceeding), authors' characteristics (number of authors, authors' reputation, self-citation, national or international collaboration, affiliation, authors' sex, age and ethnicity), and specificities of the documents (text quality, novelty, popularity, and relevance of the subject matter, field characteristics, methodology, type of document, results' characteristics, use of figures, tables and appendices, metadata characteristics and references, text extension, date of publication, citation speed).

In that sense, and as part of the discussion about the characteristics of Colombian academic publications on engineering, this article identifies the most recurrent themes of the articles published in these journals as a first step to find similarities and differences with the journals ranked in the highest quartiles and thus have the way to establish particularities that explain their citation.

This article also shows which bibliographic networks are used, i.e., the source of the references (journals and magazines) to the published articles. Specifically, following academic literature for bibliometric journal reports [5], [6] the document makes a quantitative description of published articles 
emphasizing on its number and citation averages and then, like in scientific networks research [7], [8], [9], [10] uses a cowords analysis to identify co-citation networks and issues from its keywords.

Following this introduction, the method and the information sources used are presented, the resources are shown, and the findings are discussed.

\section{MATERIALS AND METHODS}

Systematic Literature Network Analysis (SLNA), which comprises two stages, was used to analyse the articles. The first stage includes a literature review to define the universe of texts to be considered [11], [12] [13]. The study's scope and location, the search criteria, and the selection of the texts to be analysed were defined in this step. The second stage includes the analysis and the visualization of the networks. The results of this step are the maps or networks with which the proposed SLNA objective is fulfilled.

The first step showed that the working universe would include texts classified as articles published in Colombian journals of the Engineering category in the Scopus database and published between 2014 and 2018 (TABLE I). Two types of networks were built based on these articles: i) by co-occurrence of terms for keywords [14], [15], [16], and ii) by citation, to establish the sources of the references to the articles published. VOSviewer tool was used for mapping purposes [17].

TABLE I. UNIVERse OF ARTICles Published Per YeAR

\begin{tabular}{|l|l|l|l|l|l|l|}
\hline Journal & $\mathbf{2 0 1 4}$ & $\mathbf{2 0 1 5}$ & $\mathbf{2 0 1 6}$ & $\mathbf{2 0 1 7}$ & $\mathbf{2 0 1 8}$ & Total \\
\hline DYNA (Colombia) & 189 & 180 & 151 & 155 & 44 & 719 \\
\hline $\begin{array}{l}\text { Revista Facultad de } \\
\text { Ingeniería }\end{array}$ & 80 & 70 & 58 & 39 & 16 & 263 \\
\hline $\begin{array}{l}\text { Ingeniería e } \\
\text { Investigación }\end{array}$ & 42 & 57 & 41 & 40 & 26 & 206 \\
\hline $\begin{array}{l}\text { Ingeniería y } \\
\text { Universidad }\end{array}$ & 21 & 21 & 17 & 13 & 12 & 84 \\
\hline Total & $\mathbf{3 3 2}$ & $\mathbf{3 2 8}$ & $\mathbf{2 6 7}$ & $\mathbf{2 4 7}$ & $\mathbf{9 8}$ & $\mathbf{1 2 7 2}$ \\
\hline
\end{tabular}

Word co-occurrence analysis or co-words analysis was used to build the networks, leading to finding certain similarities in a set of texts based on keywords (author or journal) of the texts to analyse, so patterns or structures for the related words may be established [15]. This, because if two words appear in a text, then there are related themes, and if two words appear in two different texts, then the texts are related.

The results below show indicators of the number of publications, citation as a way to show the scientific relevance of journals [18], [19] and keyword co-occurrence and citation mapping to establish the subject matters of recent publications in Colombian engineering academic journals.

\section{RESUltS}

Colombian engineering journals in Scopus show a different dynamic from the journals ranked in the same quartile: i) fewer texts have been published in the last three years than the average of Q3 journals; ii) their number of citations during the last three years is lower than the average of Q3 journals, and iii) the citations per text for the last two years are higher than Q3 journals for Ingeniería e Investigación and Ingeniería y Universidad, and lower for DYNA and Revista Facultad de Ingeniería (TABLE II).

The comparison between the four journals selected shows differences in the number of texts published, the citations received, and their date of creation. Thus, DYNA, created in 1933, is the oldest journal and has most of the published texts. Revista de Facultad de Ingeniería, created in 1984; Ingeniería e Investigación, created in 1981, and Ingeniería y Universidad, which published its first issue in 1997, are next (TABLE III).

Furthermore, most citations are from DYNA, which has had over 200 citations for the previous three years since 2014. DYNA is followed, in order of citations, by Revista Facultad de Ingeniería, Ingeniería e Investigación, and Ingeniería y Universidad which did not exceed 100 citations in the previous three years (TABLE IV).

During the period between 2014 and October of 2018, the journals published 1,272 texts classified as articles. Most of these were published by DYNA (57\%), followed by Revista Facultad de Ingeniería (21\%), Ingeniería e Investigación (16\%), and Ingeniería y Universidad (7\%). Most of these articles (59\%) have not been cited, and DYNA has the highest percentage of articles with at least one citation (TABLE V). The range of citations of the articles is between one and sixteen citations.

Thus, Colombian engineering journals in comparison with their peers in the third quartile of Scopus are below the average number of articles published and the two- and three-years average citation. The evidence shows that as of 2018, national journals have not exceeded the barrier of 540 articles published in three years, neither 200 citations in three years. This, in the medium term, if the trend is not reversed, would point to a decrease in the classification by SJR (Scimago Journal Rank) of Colombian engineering journals.

TABLE II. TEXTS AND Number OF CitATIONS PER QUARTILE IN SCOPUS

\begin{tabular}{|l|l|l|l|}
\hline Journals & $\begin{array}{l}\text { Average } \\
\text { docs. (3 } \\
\text { years) }\end{array}$ & $\begin{array}{l}\text { Average } \\
\text { citations (3 } \\
\text { years) }\end{array}$ & $\begin{array}{l}\text { Average } \\
\text { citations/doc (2 } \\
\text { years) }\end{array}$ \\
\hline Q1 & 591 & 2294 & 2.939 \\
\hline Q2 & 364 & 339 & 0.893 \\
\hline Q3 & 544 & 267 & 0.438 \\
\hline Q4 & 233 & 49 & 0.201 \\
\hline Average & $\mathbf{4 4 0}$ & $\mathbf{7 6 7}$ & $\mathbf{1 . 1 5 8}$ \\
\hline & $\begin{array}{l}\text { No. Docs. (3 } \\
\text { years) }\end{array}$ & $\begin{array}{l}\text { No. Citations } \\
\mathbf{( 3 ~ y e a r s ) ~}\end{array}$ & $\begin{array}{l}\text { Citations/ doc (2 } \\
\text { years) }\end{array}$ \\
\hline DYNA & 532 & 200 & 0.340 \\
\hline $\begin{array}{l}\text { Ingeniería e } \\
\text { Investigación }\end{array}$ & 149 & 83 & 0.600 \\
\hline $\begin{array}{l}\text { Ingeniería y } \\
\text { Universidad }\end{array}$ & 62 & 32 & 0.690 \\
\hline $\begin{array}{l}\text { Revista Facultad } \\
\text { de Ingeniería }\end{array}$ & 219 & 68 & 0.310 \\
\hline
\end{tabular}

Source: author's calculations based on Scopus. 
TABLE III. NumBer of TeXTS PUBLISHed IN 3 YeARS

\begin{tabular}{|l|l|l|l|l|l|l|l|l|}
\hline Journal & $\mathbf{2 0 1 0}$ & $\mathbf{2 0 1 1}$ & $\mathbf{2 0 1 2}$ & $\mathbf{2 0 1 3}$ & $\mathbf{2 0 1 4}$ & $\mathbf{2 0 1 5}$ & $\mathbf{2 0 1 6}$ & $\mathbf{2 0 1 7}$ \\
\hline DYNA & 173 & 285 & 361 & 419 & 438 & 492 & 512 \\
\hline Revista Facultad de Ingeniería & 137 & 253 & 292 & 276 & 226 & 213 & 224 \\
\hline Ingeniería e Investigación & 60 & 126 & 213 & 202 & 175 & 132 & 219 \\
\hline Ingeniería y Universidad & 31 & 46 & 61 & 69 & 79 & 73 & 144 \\
\hline Total & 401 & 710 & 927 & 966 & 918 & 910 & 94 \\
\hline
\end{tabular}

TABLE IV. Number of Citations Per Journal (3 Years)

\begin{tabular}{|l|l|l|l|l|l|l|l|l|}
\hline Journal & $\mathbf{2 0 1 0}$ & $\mathbf{2 0 1 1}$ & $\mathbf{2 0 1 2}$ & $\mathbf{2 0 1 3}$ & $\mathbf{2 0 1 4}$ & $\mathbf{2 0 1 5}$ & $\mathbf{2 0 1 6}$ & $\mathbf{2 0 1 7}$ \\
\hline DYNA & 26 & 69 & 149 & 145 & 211 & 234 & 214 & 200 \\
\hline Revista Facultad de Ingeniería & 18 & 52 & 50 & 44 & 49 & 60 & 87 & 68 \\
\hline Ingeniería e Investigación & 3 & 13 & 23 & 31 & 42 & 58 & 74 & 83 \\
\hline Ingeniería y Universidad & 2 & 5 & 8 & 7 & 7 & 15 & 14 \\
\hline Total & 49 & 139 & 230 & 227 & 309 & 367 & 389 \\
\hline
\end{tabular}

TABle V. Percentage of Articles with at least One Citation

\begin{tabular}{|l|l|l|l|l|l|l|}
\hline Journal & $\mathbf{2 0 1 4}$ & $\mathbf{2 0 1 5}$ & $\mathbf{2 0 1 6}$ & $\mathbf{2 0 1 7}$ & $\mathbf{2 0 1 8}$ & Total \\
\hline DYNA (Colombia) & 63.5 & 47.8 & 38.4 & 18.7 & 6.8 & 41.2 \\
\hline Revista Facultad de Ingeniería & 46.3 & 61.4 & 27.6 & 15.4 & 12.5 & 39.5 \\
\hline Ingeniería e Investigación & 64.3 & 64.9 & 61.0 & 17.5 & 3.8 & 47.1 \\
\hline Ingeniería y Universidad & 38.1 & 71.4 & 35.3 & 15.4 & 0.0 & 36.9 \\
\hline Total & $\mathbf{5 7 . 8}$ & $\mathbf{5 5 . 2}$ & $\mathbf{3 9 . 3}$ & $\mathbf{1 7 . 8}$ & $\mathbf{6 . 1}$ \\
\hline
\end{tabular}

The keyword co-occurrence mapping with at least five repetitions, throws 48 keywords grouped in 10 clusters: i) biodiesel, decision-making, education, logistics, methodology, optimization, supply chains; ii) artificial neural networks, grouping, costs, power consumption, ergonomics, FPGA; iii) efficiency, electric vehicles, management, mathematical models, risk assessment; iv) absorption, biomass, carbon, kinetics, pyrolysis; v) genetic algorithm, harmonic distortion, parameter estimation; vi) open code, Raman spectroscopy, hyperspectral representation; vii) CFD, finite elements, temperature, friction; viii) renewable energy, energy efficiency, distributed generation; ix) quality, simulation, dynamic systems, x) pollution, sustainability (Fig. 1).

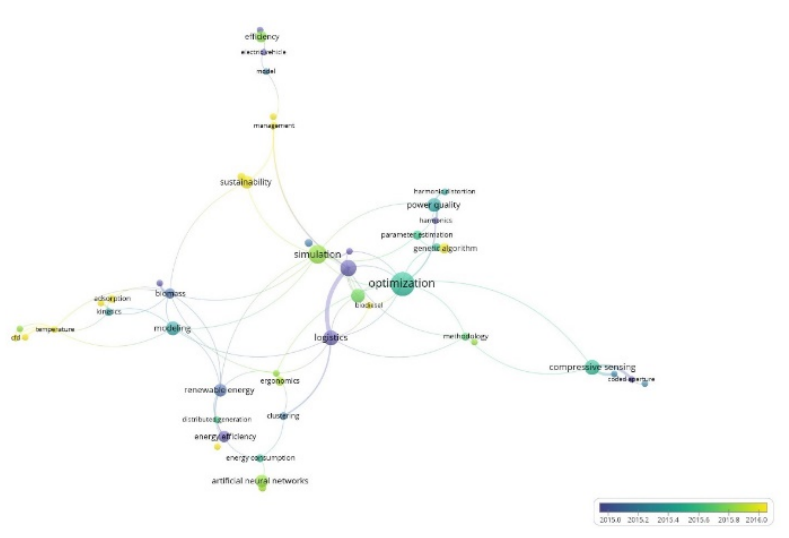

Fig. 1. Keywords Co-occurrence. Articles between 2014 and 2018.
Those clusters may be aggregated in six areas: Optimization, Humans, Energy, Materials, Simulation and algorithms, and Environment and sustainability (TABLE VI).

TABLE VI. CLUSTERS AND THEMES IN COLOMBIAN ARTICLES

\begin{tabular}{|l|l|l|}
\hline $\mathbf{N .}$ & Cluster & Area \\
\hline 1 & $\begin{array}{l}\text { Biodiesel, decision-making, education, } \\
\text { logistics, methodology, optimization, } \\
\text { supply chains; }\end{array}$ & Optimization \\
\hline 2 & $\begin{array}{l}\text { Artificial neural networks, grouping, costs, } \\
\text { power consumption, ergonomics, FPGA; }\end{array}$ & Humans \\
\hline 3 & $\begin{array}{l}\text { Efficiency, electric vehicles, management, } \\
\text { mathematical models, risk assessment; }\end{array}$ & Energy \\
\hline 4 & $\begin{array}{l}\text { Absorption, biomass, carbon, kinetics, } \\
\text { pyrolysis; }\end{array}$ & Materials \\
\hline 5 & $\begin{array}{l}\text { Genetic algorithm, harmonic distortion, } \\
\text { parameter estimation; }\end{array}$ & Optimization \\
\hline 6 & $\begin{array}{l}\text { Open code, Raman spectroscopy, } \\
\text { hyperspectral representation; }\end{array}$ & $\begin{array}{l}\text { Simulation and } \\
\text { algorithms }\end{array}$ \\
\hline 7 & CFD, finite elements, temperature, friction; & $\begin{array}{l}\text { Simulation and } \\
\text { algorithms }\end{array}$ \\
\hline 8 & $\begin{array}{l}\text { Renewable energy, energy efficiency, } \\
\text { distributed generation; }\end{array}$ & Energy \\
\hline 9 & Quality, simulation, dynamic systems, & $\begin{array}{l}\text { Simulation and } \\
\text { algorithms }\end{array}$ \\
\hline 10 & Pollution, sustainability & $\begin{array}{l}\text { Environment and } \\
\text { sustainability }\end{array}$ \\
\hline
\end{tabular}


Clusters and areas (TABLE VI) show that articles in Colombian engineering journals outline computational applications to typical engineering problems and do not deal with more recent issues such as bio or nano materials, cybernetics, geosciences or biomedical which are typical subjects in top ranked journal.

Regarding the citations by countries, the mapping shows the connection of 53 countries as sources of bibliographic references of the articles, showing Colombia, Mexico, Spain, and Brazil as the leading countries, followed by Chile, Ecuador, and Argentina, to a lesser extent (Fig. 2).

In turn, the citation per source (journal) shows that the most referenced journals by the authors of the selected articles are: DYNA (518), European Journal of Operational Research (155), Journal of Food Engineering (119), Ingeniería e Investigación (117), IEEE Transactions on Power Delivery (111), Construction and Building Materials (108) and Fuel (103) (Fig. 3).

The sources of these references (except for Ingeniería e Investigación) are associated with journals in the higher quartile, an h-indexes above 100, and articles published since the 70s. The areas covered by these journals include information systems, operations research, mathematical modelling and simulation, food science, electrical, electronic, civil, chemical, materials, and fuels engineering (TABLE VII).

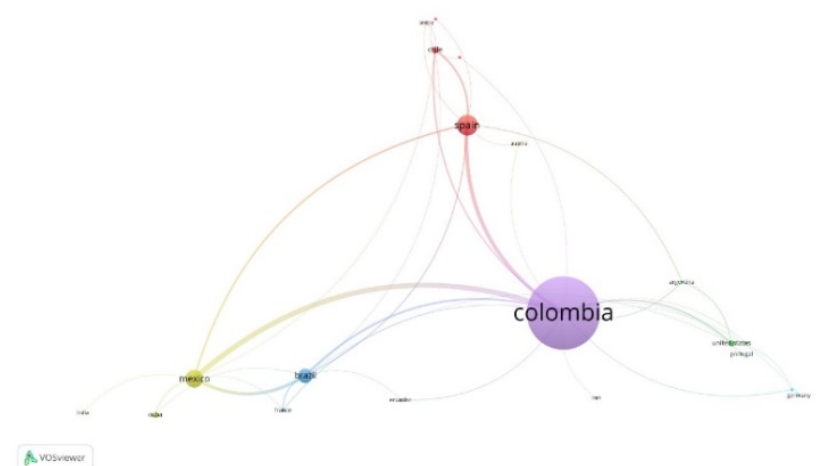

Fig. 2. Sources of the References used by Country. Articles between 2014 and 2018.

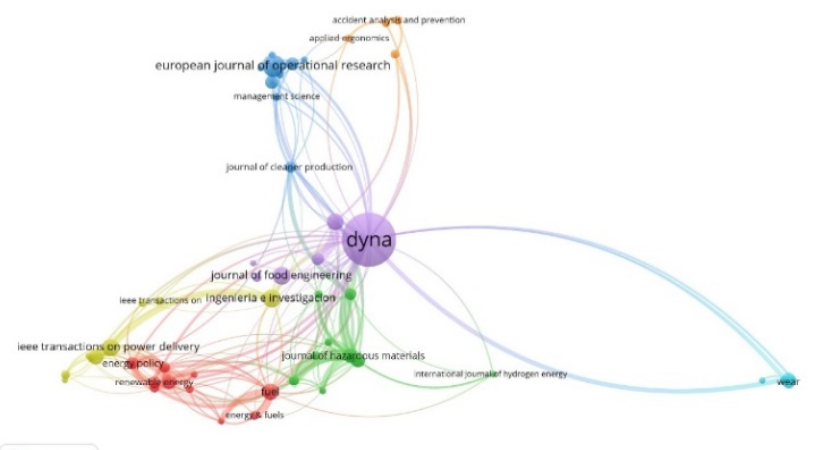

A vosviever

Fig. 3. Sources of References used by Journal. Articles between 2014 and 2018.
TABLE VII. MOST SigNIFICANT SOURCES OF REFERENCES OF COLOMBIAN ENGINEERING JOURNALS IN SCOPUS

\begin{tabular}{|c|c|c|c|c|}
\hline Journal & $\begin{array}{l}\text { Year } \\
\text { indexed } \\
\text { in } \\
\text { Scopus }\end{array}$ & Journal areas & $\begin{array}{l}\text { H- } \\
\text { Index }\end{array}$ & $\begin{array}{l}\text { SJR } \\
\text { Quartile }\end{array}$ \\
\hline Fuel & 1970 & $\begin{array}{l}\text { Chemical Engineering } \\
\text { Chemical Engineering } \\
\text { (miscellaneous) } \\
\text { Chemistry } \\
\text { Organic Chemistry } \\
\text { Energy } \\
\text { Energy Engineering and } \\
\text { Power Technology } \\
\text { Fuel Technology }\end{array}$ & 165 & Q1 \\
\hline $\begin{array}{l}\text { European } \\
\text { Journal of } \\
\text { Operational } \\
\text { Research }\end{array}$ & 1977 & $\begin{array}{l}\text { Decision Sciences } \\
\text { Information Systems and } \\
\text { Management } \\
\text { Management Science and } \\
\text { Operations Research } \\
\text { Mathematics } \\
\text { Modelling and } \\
\text { Simulation }\end{array}$ & 211 & Q1 \\
\hline $\begin{array}{l}\text { Journal of } \\
\text { Food } \\
\text { Engineering }\end{array}$ & 1982 & $\begin{array}{l}\text { Agricultural and } \\
\text { Biological Sciences } \\
\text { Food Science }\end{array}$ & 142 & Q1 \\
\hline $\begin{array}{l}\text { IEEE } \\
\text { Transactions } \\
\text { on Power } \\
\text { Delivery }\end{array}$ & 1985 & $\begin{array}{l}\text { Energy } \\
\text { Energy Engineering and } \\
\text { Power Technology } \\
\text { Engineering } \\
\text { Electrical and Electronic } \\
\text { Engineering }\end{array}$ & 152 & Q1 \\
\hline $\begin{array}{l}\text { Construction } \\
\text { and Building } \\
\text { Materials }\end{array}$ & 1987 & $\begin{array}{l}\text { Engineering } \\
\text { Building and } \\
\text { Construction } \\
\text { Civil and Structural } \\
\text { Engineering } \\
\text { Materials Science } \\
\text { Materials Science } \\
\text { (miscellaneous) }\end{array}$ & 109 & Q1 \\
\hline $\begin{array}{l}\text { Ingeniería e } \\
\text { Investigación }\end{array}$ & 2009 & $\begin{array}{l}\text { Engineering } \\
\text { Engineering } \\
\text { (miscellaneous) }\end{array}$ & 7 & Q3 \\
\hline
\end{tabular}

Co-words analysis shows close relationships between Colombian engineering journals and those from Spanishspeaking countries as reference sources, which is aligned with the origins and circulation of the published articles. On the one hand, most of the articles published in Colombian journals are in Spanish, which limits the access of English-speaking communities. On the other hand, if the references come from Spanish articles written in Latin America, it would be expected that the research that give rise to the articles published were about local problems and not about global coverage or those dealt with in the Scopus' Q1 or Q2 journals that have the greatest impact.

\section{DISCUSSION AND CONCLUSIONS}

The findings for Colombian engineering journals in Scopus show a similar behaviour to those of Colombian journals in Scielo [1] regarding the source of the texts and the collaboration between authors. In engineering and the aggregate of Colombian journals, most texts are signed by authors affiliated to Colombia and with some participation by Spain, Brazil, and other Latin American countries. This may be a sign of preference for certain local themes and of limited 
possibilities for progress on themes with greater global coverage or with particular needs (laboratories, equipment, reagents) for research.

The journal DYNA of Universidad Nacional de Colombia shows the best results on the number of articles published, the number of citations of its articles, and the number of times it is referenced in other journal articles. This may be because i) it is a traditional publication created by the first school of mines in Colombia, dating to the $19^{\text {th }}$ century and which would become the Faculty of Mines of Universidad Nacional de Colombia in 1944; ii) it is the oldest publication, and iii) it is the Colombian engineering magazine indexed in Scopus with the most published articles.

Over the last few years, Colombian engineering academic journals published mostly articles on optimizing supply chains and logistics (77\%), implying work with information that requires minimal laboratory experimentation. In this same vein of research that does not necessarily involve large deployments of laboratory equipment, works with applications of artificial neural networks, clustering, and genetic algorithms stand out. That may be a consequence of low investments in technology (Colombia's investment in research and development in 2018 was $0,28 \%$ of GDP), deficiencies in higher education and its training objectives, and a low appropriation of science.

To a lesser extent (10\%), texts showing the results of biomass analysis and on energy and sustainability were also published. The articles published mostly reference texts from Spanish-speaking countries. Colombia, Mexico, Spain, Chile, Argentina, Ecuador, and from the journals DYNA, European Journal of Operational Research, Journal of Food Engineering and Ingeniería e Investigación.

Thus, relevant themes of the Colombian engineering journals available in Scopus aim cover some of the conventional aspects of industrial engineering with hints of chemical engineering, mining engineering, food engineering, and artificial intelligence applications (neural networks, genetic algorithms), which contrasts with more recent engineering issues in international literature and which are present in the journals ranked in the higher quartiles (1 and 2), with higher citations: materials, physics, and astronomy, biophysics, biochemistry, ceramics, biotechnology or biomedical engineering, in which countries such as Brazil, Russia, India, and China have had significant progress [20]. This difference in subject matters may explain the low citation of articles-16 citations in the articles with the most citations in the last five years - and citations below the average for journals ranked in quartile 3.

Indeed, a research panorama emerges to clarify the reasons for those themes in Colombian journals, drawing the following hypothesis: i) the technological characteristics of the Colombian industry that includes low productivity, little national set of companies and major exports in commodities imply that the national academic literature on engineering does not deal with recent themes addressed by the international academy; ii) Colombian authors dealing with more global themes belong to international researchers networks that submit their work to international journals ranked in higher quartiles; or iii) the Colombian academy does not have the physical capital (laboratories, instruments, servers) to conduct research that results in publications aligned with the most recently cited themes.

It is also pertinent to investigate whether there are other causes-outside research-for the articles on more recent themes not to reach Colombian engineering journals, such as the low number of volumes published, speed of response to reviews, SJR results, and the language.

\section{REFERENCES}

[1] Maz-Machado, N. N. Jiménez-Fanjul y M. E. Villarraga, «La producción científica colombiana en SciELO: un análisis bibliométrico,» Revista Interamericana de Bibliotecología, vol. 39, n 2, pp. 111-119, 2016.

[2] J. I. Rojas-Sola y C. De San-Antonio-Gómez, «Análisis bibliométrico de las publicaciones científicas colombiana en la categoría engineering, multidisciplinary de la base de datos Web of Science (1997-2009),» Dyna. 77 (164), pp. 9-17, 2010.

[3] M. Aguilera-Prado, C. Aguirre y O. Salcedo, «Approach to Citation Determinants of Articles from Colombian Engineering Journals in Scopus,» Contemporary Engineering Sciences, vol. 10, n ${ }^{\circ} 26$, pp. 12791286, 2017.

[4] I. Tahamtan, A. Safipour Afshar y K. Ahamdzadeh, «Factors affecting number of citations: a comprehensive review of the literature,» Scientometrics 107, pp. 1195-1225, 2016.

[5] R. P. Leone, L. M. Robinson, J. Bragge y O. Somervuori, «A citation and profiling analysis of pricing research from 1980 to 2010,» Journal of Business Research 65, p. 1010-1024, 2012.

[6] C. Lokker, A. McKibbon, R. J. McKinlay, N. L. Wilczynski y B. Haynes, «Prediction of Citation Counts for Clinical Articles at Two Years Using Data Available within Three Weeks of Publication: Retrospective Cohort Study,» British Medical Journal, vol. 336, $\mathrm{n}^{\circ} 7645$, pp. 655-657, 2008.

[7] J. Xi, S. Kraus, M. Filser y F. Kellermans, «Mapping the field of family business research: past trends and future directions,» International Entrepreunership Management Journal, vol. 11, pp. 113-132, 2015.

[8] J.-l. Hung, «Trends of e-learning research from 2000 to 2008: Use of text mining and bibliometrics,» British Journal of Educational Technology, pp. 5-16, 2012.

[9] R. N. Kostoff, D. R. Toothman, H. J. Eberhart y J. A. Humenik, «Text mining using database tomography and bibliometrics: A review,» Technological Forecasting \& Social Change 68, pp. 223-253, 2001.

[10] K. W. Boyack, D. Newman, R. J. Duhon, R. Klavans, M. Patek, J. R. Biberstine, B. Schijvenaars, A. Skupin, N. Ma y K. Börner, «Clustering More than Two Million Biomedical Publications: Comparing the Accuracies of Nine Text-Based Similarity Approaches,» PLOS One, vol. 6, n ${ }^{\circ}$ 3, pp. 1-11, 2011.

[11] C. Colicchia y F. Strozzi, «Supply chain risk management: a new methodology for a systematic literature review,» Supply Chain Management: An International Journal, vol. 17, nº 4, pp. 403-418, 2012.

[12] F. Strozzi, C. Colicchia, A. Creazza y C. Noè, «Literature review on the 'Smart Factory' concept using bibliometric tools,» International Journal of of Production Research, vol. 55, n 22, pp. 6572-6591, 2017.

[13] F. Kithous, F. Strozzi, A. Urbinati y F. Alberti, «A Systematic Literature Network Analysis of Existing Themes and Emerging Research Trends in Circular Economy,» Sustainability, vol. 12, n 4, pp. 1633-1657, 2020.

[14] J. Charum, «Generación de un sistema de información y construcción de indicadores de las acumulaciones y de las dinámicas sociales y cientítficas de las Red Caldas,» de Hacer ciencia en un mundo globalizado. La diáspora científica colombiana en perspectiva, J. Charum y J. Meyer, Edits., Bogotá, Tercer Mundo, 1998, pp. 5-40.

[15] N. J. van Eck y L. Waltman, «How to normalize co-occurrence data? An analysis of some well-known similarity measures,» Journal of the American Society for Information Science and Technology 60, pp. 1635-1651, 2009.

[16] D. H. Rodríguez y C. E. Pardo, «Programación en R del método de las palabras asociadas,» Universidad Nacional de Colombia, Bogotá, 2007. 
[17] N. J. van Eck y L. Waltman, «Software survey: VOSviewer, a computer program for bibliometric mapping,» Scientometrics, $n^{\circ}$ 84, pp. 523-538, 2010.

[18] J. González , M. Moya y M. A. Mateos, «Indicadores bibliométricos: características y limitaciones en el análisis de la actividad científica,» Anales Españoles de Pediatría, vol. 47, no 3, pp. 235-244, 1997.
[19] D. Aksnes, L. Langfeltdt y P. Wouters, «Citations, Citation Indicators, and Research Quality: An Overview of Basic Concepts and Theories,» SAGE Open, pp. 1-17, 2019.

[20] B. Elango, «A bibliometric analysis of literature onengineering research among BRIC countries,» Collection and Curation, vol. $38, \mathrm{n}^{\circ} 1$, pp. 914, 2019. 